\title{
The Meaning of Financial Accounting Standards for Micro, Small and Medium Entities (SAK EMKM) During The Covid- 19 Pandemic
}

\author{
LILIK PURWANTI ${ }^{1}$, DIAN SURYA AYU FATMAWATI ${ }^{2}$ \\ ${ }^{1}$ Accounting Department, BRAWIJAYA UNIVERSITY, INDONESIA. E-mail: lilik@ub.ac.id \\ ${ }^{2}$ Accounting Department, BRAWIJAYA UNIVERSITY, INDONESIA. E-mail: dyansurya76@gmail.com
}

\begin{abstract}
This study aims to explore the meaning of Financial Accounting Standard for MSMEs perspective of MSMEs actors at Covid-19 pandemic. The research was conducted on MSMEs in Batu City using 4 selected MSMEs as object and informant which representing the exhibition in Dubai 2020. Data collection method by interviewing those informants and analyzed using qualitative analysis methods. The results shows that SAK EMKM is various interpretations by MSMEs actors which some usefull and not. MSMEs actors interpret that SAK EMKM as the Helper God, as antique, as increase the workload. One of the MSMEs actors considers SAK MSME to be a God of Help during the economic crisis due to the Covid-19 pandemic because increasing demand and SAK EMKM helpful for provide financial statements with SAK EMKM as qualify banks require for additional loan for business capital. The other, think that SAK EMKM as Antiques in huge loss business condition. The last, SAK EMKM is considered to increase the workload. MSME actors only think about producing and marketing their products, so financial reporting just takes more time and workload. The difference perspective was caused by level of their educational background
\end{abstract}

Keywords: Covid-19; MSMEs; Qualitative Research; SAK EMKM.

JEL Classification: A14, D90, F61M G50, H75

Received: June 02, 2021

Accepted: September 11, 2021 


\title{
El Significado de las Normas de Contabilidad Financiera para las Micro, Pequeñas y Medianas Entidades (SAK EMKM) durante la Pandemia de Covid-19
}

\author{
LILIK PURWANTI ${ }^{1}$, DIAN SURYA AYU FATMAWATI ${ }^{2}$ \\ ${ }^{1}$ Accounting Department, BRAWIJAYA UNIVERSITY, INDONESIA. E-mail: lilik@ub.ac.id \\ ${ }^{2}$ Accounting Department, BRAWIJAYA UNIVERSITY, INDONESIA. E-mail: dyansurya76@gmail.com
}

\begin{abstract}
RESUMEN
Este estudio tiene como objetivo explorar el significado de la Norma de Contabilidad Financiera para las MIPYMES desde la perspectiva de los actores de las MIPYMES en la pandemia de Covid-19. La investigación se llevó a cabo en las MIPYMES de la ciudad de Batu utilizando 4 MIPYMES seleccionadas como objeto e informantes que representan la exposición en Dubai 2020. El método de recogida de datos consistió en entrevistar a estos informantes y se analizó mediante métodos de análisis cualitativos. Los resultados muestran que SAK EMKM tiene varias interpretaciones por parte de los actores de las MIPYMES, algunas de las cuales son útiles y otras no. Los actores de las MIPYMES interpretan que el SAK EMKM es el Dios ayudante, como una antigüedad, como un aumento de la carga de trabajo. Uno de los actores de las MIPYMES considera que SAK EMKM es un Dios de ayuda durante la crisis económica debido a la pandemia de Covid-19 porque el aumento de la demanda y SAK EMKM útil para proporcionar los estados financieros con SAK EMKM como calificar los bancos requieren para el préstamo adicional para el capital empresarial. El otro, pensar que SAK EMKM como Antigüedades en condición de negocio de gran pérdida. Por último, se considera que el SAK EMKM aumenta la carga de trabajo. Los actores de las MIPYMES sólo piensan en producir y comercializar sus productos, por lo que la presentación de informes financieros requiere más tiempo y carga de trabajo. La perspectiva de la diferencia fue causada por el nivel de su formación educativa
\end{abstract}

Palabras clave: Covid-19; MIPYMES; Investigación cualitativa; SAK EMKM.

Clasificación JEL: A14, D90, F61M G50, H75

Recibido: 02 de Junio de 2021

Aceptado: 11 de Septiembre de 2021 


\section{Introduction}

The Corona Virus 19 (Covid-19) pandemic is not only a health disaster, but also caused chaos many sectors including economic. The impact not only for large industries but also on Micro, Small and Medium Enterprises (MSMEs). The pandemic changes many things from how to live, think and the way of massively (Althafairi et. el., 2019), even the way of interaction patterns, even on business behavior in most of the world's people (Sinha et. al., 2021). During the pandemic, this sector was most affected and many of these entrepreneurs had to go out of business due to falling demand. In the survey results, Bank Indonesia stated that as many as 87.5 percent of MSMEs were affected by the Covid-19 pandemic. around 93.2 percent from thas number were negatively affected on the sales side. According to a survey conducted by the central bank, the pandemic has put pressure on revenues, profits, and cash flow, so businesses choose to wait and see. However, apparently not all MSMEs are affected by the pandemic. Bank Indonesia (BI) revealed that there were 12.5 percent of respondents who free from pandemic impact, and even 27.6 percent of them showed an increase in sales (Saputra, 2021). This is because there are various MSME sectors that can adapt and are able to innovate online sales and some cannot. Online sales are the strategy of many large companies (Nair, 2021 \& Kee et. al, 2021) and various MSMEs trying to survive (Prayitno et.el, 2020 \& Prihandoko et. al 2020).

The government has made various efforts to be able to help MSMEs get through various difficulties during the pandemic. One of the national economic recovery efforts carried out by the government during the pandemic is to encourage the MSME, that has main role in national economics because of the large number of workers who are directly involved. Moreover, the number of MSMEs in Indonesia reaches 64.19 million, with the composition of Micro and Small Enterprises (UMK) very dominant, namely 64.13 million (99.92\%) (Santia, 2020) of the entire business sector. This group also feels the negative impact of the Covid-19 pandemic. In this crisis situation, MSME sector need more attention because that conribution to GDP and effective in employment and replace the production of consumer goods or semi-finished goods (IAI, 2016a). Moreover, amid positive sentiment that economic conditions will improve this year, the MSMEs sector must be able to take advantage of the current economic growth momentum to recover. This paper examines the condition of MSMEs due to the economic slowdown that emerged due to the Covid-19 pandemic and how the government's efforts to encourage MSMEs are by taking advantage of the momentum of national economic recovery in the Covid-19 virus pandemic.

MSMEs actors are also in an effort to maintain their business by reducing the production of goods/services, reducing working hours and the number of employees and sales/marketing channels. Even so, there are also MSMEs who take the opposite step, namely adding marketing channels as part of their survival strategy (Katadata.co.id, 2020). Meanwhile, the results of a survey of 20 from several institutions such as BPS, Bappenas, and the World Bank show that this pandemic has caused many MSMEs to have difficulty paying off loans as well as paying bills for electricity, gas, and employee salaries. Some of them even had to do layoffs. Other obstacles experienced by MSMEs include difficulty in obtaining raw materials, capital, declining customers, distribution and production being hampered. In addition, changes in Consumer Behavior and the Business Competition Map also need to be anticipated by business actors due to activity restrictions. Consumers do more activities at home by utilizing digital technology. Therefore, all the difficulties and variations made by MSMEs actors are closely related to future accounting decisions.

MSMEs are businesses that give a major contribution to boost Indonesia's economics. MSMEs are one of the national economy strengthening components the because of their strong, dynamic, and efficient characteristics. MSMEs also proven be able to encourage domestic economic growth by 60 percent and at the same time absorb 97 percent of the productive workforce in Indonesia. In addition, MSMEs also play a role as a buffer for the national economy in times of crisis. MSMEs as a driving force of the Indonesian economy because the great contribute to the development and growth of this country. According to the source from the Central Statistics Agency (BPS) in Liputan6.com, the number of MSMEs in Indonesia reaches 65 million or 99.9 percent of the total business units in Indonesia. The 
Indonesian Ministry of Cooperatives and SMEs reports that MSMEs have about $99.99 \%$ market of the total in Indonesia (2017), while large businesses are only $0.01 \%$ or about 5400 units. Micro enterprises employee about 107.2 million workers (89.2\%), Small Businesses 5.7 million (4.74\%) and Medium Enterprises 3.73 million (3.11\%); while Large Enterprises employee about 3.58 million people. So, MSMEs employee about $97 \%$ of the national workforce, while large businesses only $3 \%$ of the total national workforce (Haryanti \& Hidayah, 2018).

Financial reports are a cricial element for the sustainability of MSMEs businesses. The Accurate financial reports can be used to determine the financial position, as a decision-making tool, and the requirements for applying for a loan to a bank. Alfitri et. al (2014) showed that the recording and preparation of financial statements is needed by MSME actors to find out the financial position and performance of the company more accurately and relevantly. There are regulations that require MSMEs to compile books of business activities, as Government Regulation of the Republic of Indonesia Number 17 of 2013 concerning the implementation of Law Number 20 of 2008 concerning Micro, Small and Medium Enterprises. However, in reality there are still many MSMEs that do not provide financial reports that meet standards. This prompted the Financial Accounting Standards Board of the Indonesian Institute of Accountants (DSAK IAI) to issue standards aimed at meeting financial reporting needs for MSMEs, namely the SAK EMKM were effective 1 January 2018 (IAI, 2016b). To make understanding the financial statements easier, it is necessary to have standards as guidelines in their preparation (Lestari \& Priyadi, 2017). With the existence of SAK EMKM, make MSMEs actors in preparing financial reports appropriately without having to face difficulties.

One of the MSME sectors that has considerable potential in Batu City. As a tourist destination, Batu City have many opportunities business. No wonder the Batu City MSMEs sector thrives. Currently, there are nearly 24,000 MSMEs from various sectors registered with the Batu City Cooperative, MicroEnterprise and Trade Office. The number of tourists visiting, creating great opportunities for MSMEs in Batu City and MSME actors have no difficulty in marketing their products. The growth of MSMEs in Batu City is growth fast. Moreover, many MSMEs products from Batu have given nickname De Kleine Switzerland export their products. That made Batu City as representative the East Java Provincial Industry and Trade Office to represent Indonesia in the world-class trade exhibition, World Expo 2020 Dubai. In the exhibition Batu City sent 10 of its best MSMEs. The SMEs in Batu City that were included were Arjuna Flora, Arjuna 999, CV Deltras and UD Tohu.

This study tries to reveal the meaning of SAK EMKM from the perspective of MSMEs actors in Batu. During the Covid-19 pandemic, Is MSMEs still consider it important to present financial reports according to SAK EMKM or vice versa, while many MSMEs have the economic impact of pandemic. The pandemic gave a huge impact on business actors and the sustainability of MSMEs in Batu City. Many business actors are in debt because visits from tourists have decreased dramatically. This research is the first research that discusses the understanding related to SAK EMKM in a pandemic condition that changes many perspectives and also provides various new understandings due to the Covid 19 pandemic in Indonesia. Finally, results of this study provide benefits for MSMEs actors that the Covid19 pandemic does not remove the obligation to set up financial reports according SAK EMKM. It is useful for knowing business performance, calculating taxes and applying for bank credit.

\section{Literature Review}

\subsection{Micro, Small and Medium Enterprises (MSMEs)}

MSMEs act an important role. Even large businesses, in order to be agile, must behave like interconnected small businesses. Small and medium enterprises (not conglomerates), as well as middle technology (not high technology) are important to be developed for human-oriented development. Attention to small businesses began to emerge when President Soeharto planned the National Business Partnership Movement on May 15, 1996. President Soeharto said that business partnerships should not create a burden that burdens the people because the purpose of partnerships is to limit the concentration of economic power which has an impact on business inequality. 
Latest, PP Number 7 of 2021 (Presiden RI, 2021) concerning the convenience, protection and empowerment of cooperatives and MSMEs categorizes MSMEs based on business capital or annual sales results. Where for micro businesses have a maximum business capital of 1 billion excluding land and buildings or a maximum annual income of 2 billion. Small business capital excluding land and buildings is around 2-5 billion or an annual income of 2-15 billion. Meanwhile, medium-sized enterprises are 5-10 billion for capital excluding land and buildings or annual income of 15-50 billion. Meanwhile, BPS classifies based on the number of workers as follows:

Table 1 Classification of MSMEs based on the number of workers

\begin{tabular}{|c|c|c|}
\hline No & Classification & Number Of Workers \\
\hline 1 & Micro Business & $1-19$ \\
\hline 2 & Small Business & $20-99$ \\
\hline 3 & Medium Business & Minimal 100 \\
\hline
\end{tabular}

MSMEs are community groups that combine and utilize appropriately their personal, financial and environmental characteristics which are one of the stimulants of national economic growth and been recognized as one of the most value business sectors, due to various real roles in the economy. First, GDP's contribution about $63.58 \%$, second employee $99.45 \%$ third total of unit business about $99.84 \%$ and last total export value about $18.72 \%$. Besides that, the existence of MSMEs itself is one of the alternative efforts to overcome poverty through empowering MSMEs which have been proven to have relatively strong resilience in facing the economic crisis that has been experienced by the Indonesian nation. Although we are all aware that MSMEs received less attention in Indonesia before the crisis broke out in 1997. However, since the economic crisis hit Indonesia (which has brought down many large businesses) most SMEs have remained, even the number is increasing rapidly, attention to MSMEs has become a concern. larger, stronger MSMEs are also supported by their capital structure which is more dependent on own capital (73\%), $4 \%$ private banks, $11 \%$ state banks, and $3 \%$ suppliers.

\subsection{Financial Report based on SAK EMKM}

The Indonesian Institute of Accountants (IAI) has issued SAK EMKM to help Indonesian MSMEs become more transparent, efficient, and accountable. This aspect has been the biggest challenge for Indonesian MSMEs in accessing capital from financial institutions, thus hampering the growth and role of MSMEs as the pillars of the Indonesian economy in the future. MSMEs are proven to have encouraged and stimulated sustainable national economic growth so that they significantly contribute to reducing unemployment in Indonesia. Since importance of that role, all parties are expected to take a role for develop and realize the advanced, independent, and modern MSMEs. SAK EMKM is expected to help MSMEs adopt from accrual based to cash-based. That issues of SAK EMKM is expected as a drivers of financial literacy for MSMEs taht given wider access to financing from the banking industry. In the future, SAK EMKM is also expected to be the basis for the preparation and development of accounting guidelines or guidelines for MSMEs engaged in various business. This SAK EMKM has been effective since January 1, 2018 with early application allowed.

The main purpose of issuing financial statements is information that can be used for strategic decision making for the business (IAI, 2016c). Financial reports for MSMEs are also a reflection of the activities that occur in the business, whether they are going well or not. A complete financial report according to SAK EMKM consists of a financial position, profit and loss, and notes to the financial statements including additions and details of certain relevant items.

The SAK EMKM financial statements use basic assumptions are basis of accruals, going concern, and the concept of business entities. The accrual basis as a part of the entity's financial statements aims to minimize the risk of loss to MSMEs. The accrual basis is considered more accountable because it is able to record transactions when they occur and is more accurate in assessing liabilities, equity and assets. Going concern means that management uses SAK EMKM to evaluate entity's ability to business sustain in any future situation. Entity's going concern means if management have not intends to liquidate or stop the entity operations. The concept of a business entity is whether a sole proprietorship, a nonlegal entity or a legal entity, must be clearly separated from business actors and other entities. This 
separation also applies in terms of business transactions that occur between business actors and other entity transactions ${ }^{1}$.

\subsection{Perception as a Point of View SAK EMKM}

As individual and social beings, humans have differences between one person and another. Differences can cause differences in viewing an object. This depends on how people responds or perceives objects. Attitudes and behavior are determined by their perceptions. Perception is an important concept in psychology. Through perception, humans can see the world, whether the world looks bright, pale, or black. Everyone's perception of an object can be different from one person to another. According to Rakhmat (2005) the word perception in English is "perception" which means seeing, responding, understanding or responding to something. Perception describes how a person sees something. Formally, it is a process for selects, organizes, and scanning things into a broader picture (world) that has meaning and is comprehensive.

Atkinson et. el. (1991) suggest that perception is the process by which we interpret and organize stimulus patterns in the environment. Perception is a cognitive process experienced by a person in understanding information about his environment, either through sight, hearing, appreciation, feeling, and smell. The key to understanding perception lies in recognizing that perception is a unique interpretation of the situation, rather than a correct recording of the situation. Sarwono \& Meinarno (2010) says that perception is a combination of sensations received by the organs and the results of their interpretation (the results of brain processing). Sensations are stimulants from the outside world that are brought into the nervous system. Almost everything in this world is brought in by the senses through sensation.

\section{Methodology}

\subsection{Types of Research}

The qualitative methods in this research to understand the perception, motivation, action, etc., holistically, and way of description the form of words and language from the subject research phenomenon using various scientific methods (Moleong, 2016). Qualitative descriptive research is designed to collect data that describes the characteristics of people, events, or circumstances. By using a descriptive qualitative approach, researchers will describe the results of the study in the form of descriptions that show how MSME actors in Batu city interpret SAK EMKM in compiling financial reports during the Covid-19 pandemic.

\subsection{Research Site}

Sugiyono (2012) states that the object of research is an attribute, nature, value of people, objects or activities that have certain variations which are determined by researchers to be studied and be drawn the conclusions. This Research site in Batu City using object MSME actors. The reason for choosing the research site is the large number of MSMEs with very potential tourism potential. The informants are MSME actors who were chosen to represent the city of Batu to the international event in Dubai 2020, namely Arjuna Flora from Tulungrejo Village, Bumiaji District with ornamental flower products, Arjuna 999 with food and beverage products from Sidomulyo Village, Batu District and CV Deltras and UD Tohu in the Village /Junrejo District with woodworking. 


\subsection{Informants, Information Collection Methods and Data Processing}

\subsubsection{Informant}

The informants in this study were MSME actors in Batu City who were selected to represent the exhibition in Dubai. The list of informants is presented in the following table.

Table 2 Informan List

\begin{tabular}{|c|c|c|c|}
\hline No & MSMEs & Actors $^{*}$ & Type Of Biusiness \\
\hline 1 & Arjuna Flora & Ana Syafira (AS) & Decorative Flower \\
\hline 2 & Arjuna 999 & Sukir Manto (SM) & Food and Beverage \\
\hline 3 & CV Deltras & Slamet Kabul (SK) & Woodcraft \\
\hline 4 & UD Tohu & Djoko Lelono (DL) & Woodcraft \\
\hline
\end{tabular}

\subsubsection{Information Collection}

This research using the primary data which information obtained directly by researchers which relates to variables of interest for certain research purposes. Data were obtained through in-depth interviews with selected informants. Moleong states that the interview is a conversation with a specific purpose that consist of interviewer and the interviewee. The type of interview is semi-structured in depth.

\subsubsection{Data Processing}

Miles et.al. (2014) \& Sekaran (2013) state if data analysis activities qualitative research is interactively, including data condensation, data display and conclusion drawing as shown below (Fig. 1).

Figure 1 Interactive Analysis Model Schematic

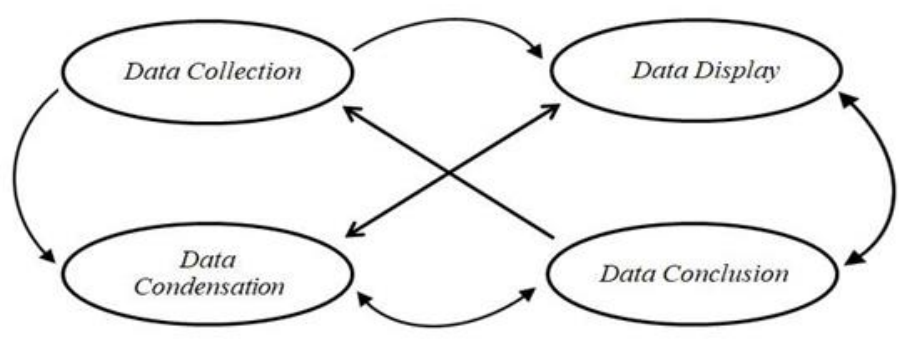

Source: Miles et.al (2014)

\section{Results and Discussion}

\subsection{SAK EMKM as The Helper God}

The Covid-19 pandemic make huge loss for MSMEs actors because decrease the revenue extremly, but not for ornamental flower sellers. Ornamental flowers actually have great revenue from this pandemic. The demand for flowers is increasing because many employees work from home so there is more time for gardening. The following is the story of the AS as an ornamental flower entrepreneur:

"Alhamdulillah, Covid-19 has brought us blessing for ornamental flower entrepreneurs because many mothers buy ornamental flowers to plant in their yards. He said he took a lot of time because he worked from home so he used it for gardening and tidying up the garden. Our income has almost doubled as the demand for ornamental flowers has increased. Moreover, the demand for Aglonema flowers, which are quite expensive, is profitable for us."

The increase in demand for various flowers, of course, requires additional capital for MSME actors. Business capital can be obtained from banks on the condition that one of the MSMEs must have 
financial statements. SMEs are aware of these requirements. The following is the AS opinion about the importance of MSMEs in preparing financial reports.

"Financial reports prepared based on standards must exist, if MSMEs apply for credit. Imagine if someone wants to borrow money from you, but you don't know when that person will be able to repay the loan, their ability, or whether you will lose money from the loan or not. I really understand that financial statements are a condition for applying for credit. Financial statements must be requested if you want to borrow capital. The bank definitely wants to know how much its turnover is, the profit or loss of its business and so on."

AS continued his explanation about the seriousness of compiling financial reports based on SAK EMKM because he considered SAK EMKM as a God of Help when he needed additional capital. Here's the AS story:

"I asked my son to help prepare financial statements. Incidentally, my son graduated from economics, so he can quickly understand the standards in preparing financial statements. So, The God still in my side with our efforts during the Covid-19 pandemic. How come? When demand increases and additional capital is needed, we are able to provide financial reports. Even though I was forced to study SAK EMKM and it turned out to be very useful. That's why I say that SAK EMKM is the God of Help for our business"

Based on the results of the discussion above, it can be concluded that the SAK EMKMs financial are required as a condition for applying for credit. In addition, there are many other benefits, namely to know business continuity, to make decisions, to calculate taxes and so on. MSMEs actors interpret SAK EMKM as a God of Help when they need capital to support and develop their business. This makes MSMEs actors aware of how significant to understand and set up SAK EMKMs financial reports.

At the ploicymakers percpective, SAK EMKM is a simplified form of PSAK used by large companies to achieve public accountability. This form of simplification is expected to be able to present EMKM accountability by summarizing the required requirements so that EMKM resources are able to fulfill them. The accountability presented through SAK EMKM certainly provide some conveniences for EMKM compared to PSAK that have more reporting requirements. One of the impacts of EMKM accountability is making it easier to achieve more capital for banking entities. By having a form of accountability by implementing SAK EMKM, banks and other sources of capital feel safer in providing additional capital, this is a form of reducing the information asymmetry that exists between agents (EMKM) and principals (banks and other financial institutions).

\subsection{SAK EMKM as Antique}

The Effect of Covid-19 pandemic has been deeply felt by wood craftsmen in Batu. Income has decreased drastically due to very less tourists visiting, as a result the debt is increasing because there is an employee salary burden that must be paid every week. Here's the opinion of DL a wood craftsman:

"It's very impactful, I even lost an order from a distributor from Surabaya who usually sends products abroad such as China, Malaysia and outside the city. Revenue fell from 80 million to only 10 million, while weekly expenses were around 6 million to support employees. Now I have a debt to 15 employees for five weeks".

The same opinion was conveyed by SK in the following profession with DL:

"Small entrepreneurs like us really feel the impact of the Covid-19 pandemic. We rely on local and foreign tourists to market our products in the form of stationery boxes, tissue holders, folding tables, folding chairs, cosmetic boxes and various souvenirs. Since the 2020 pandemic our product sales have fallen sharply and have had to reduce employees because they cannot afford to pay."

In conditions of economic pressure due to the Covid-19 pandemic, MSMEs actors no longer think about books or financial reports that must be prepared according to SAK EMKM. They consider SAK EMKM to be an antique which is expensive and should not be touched for fear of breaking. They just 
think how their business can survive and start thinking about selling their products online. In fact, MSMEs actors really understand the importance of Financial Reports that are prepared according to SAK EMKM. Here's the DL explanation:

"In the past, I compiled books and financial reports because there were reports. Now it is difficult to pay employee salaries and family living expenses. So we think that the standard is only an antique, the price is expensive and we must take care not to damage it or break it, hey, he said with laughing.

After the laughter, DL continued his story.

"Before the pandemic, my son helped to compile financial reports, only the Income Statement and Cash Flow Statement for credit applications and tax calculations. He said he had referred to the standards for SMEs. Now we forget about that standard for a while and have to think hard about how our products sell. We started pioneering online sales through Facebook, Instagram and exploring opportunities to enter Bukalapak, Tokopedia and Shopee".

The same view according to the SK of the wood craftsman, financial statements must be made to find out whether our business is profitable or not. Here's the SC's explanation:

"We have made financial reports but we don't know whether it's true or not. First we make an income statement, all income from sales goes in as well as for expenditure on materials included in the report as an expense. From the difference between total income and expenses, it can be seen that our business is profiting or losing. We make monthly reports. Besides that, we arrange business assets even though it is simple but we know what assets we have".

SK continued his explanation:

"SAK EMKM is very important as a guideline for preparing financial reports to determine business success but at this time we are not thinking about standards. We think of the standard as just a display, very beautiful but can only be seen. Far from our minds and may have to be forgotten for a while haa haa", he said with a big laugh.

Based on the description of the opinion of the informant above, SAK EMKM is considered an antique, as a display that should not be touched during this Covid-19 pandemic. Although before the pandemic there were those who compiled financial reports but not during the pandemic. Moreover, it must be compiled in accordance with SAK EMKM, even though MSMEs actors are very aware of that.

Respondents' perception that the standard of an antique is actually related to the perception of the exclusivity of accounting standards. Even though accounting as a business language, not all have the ability to prepare it, let alone meet the standards. As a result, the preparation of reports often uses a third party to fulfill this aspect of the need for accountability, and in the conditions of the pandemic and the sluggish economy, the costs required are even greater so they choose not to compile it during a pandemic. Therefore, this perception implicitly conveys that there is a need for a bridge from the compilers that the preparation can be achieved by various groups independently through socializing the ease of preparing financial reports based on SAK EMKM.

\subsection{SAK EMKM as Increase The Workload}

During the COVID-19 pandemic, MSME actors considered SAK EMKM to be less important and almost all informants stated that their business was still running without financial reports. The reason behind the informants not compiling financial reports according to SAK EMKM is that they do not have free time to read and understand the standards because they are busy focusing on the production process and product marketing. It is as expressed by SK:

"If there is a purchase, for example we are purchase for wood, nails and others, we will get a note, that's the note that we record. There is no detailed accounting yet. Don't say no, ma'am. There are only three of us whose work is divided. Yes, please understand because there are a lot of people who think about it, hee hee".

SM has the same opinion as conveyed by SK, as explained below. 
"We've been busy with cooking and preparing sales, so I don't think we have time to make financial reports. The financial statements have not been prepared because they can't afford it and it feels like they don't have the time. Only incoming notes and outgoing notes are recorded. Moreover, you have to arrange according to the standard," he said, taking a deep breath.

Then SM continues the story:

"During this pandemic, the rules for financial reporting are less important. We only think how the business can survive and we can provide for the family. There are many costs that must still be incurred such as living expenses, children's school fees and others, so I forget about financial reports and standards".

DL also complained that he did not have time to compile financial reports during the Covid-19 pandemic. Understanding SAK EMKM takes quite a long time so it only adds to the burden of thought. Here's DL's answer:

"Before the pandemic, I had compiled financial reports, even though they were only Income Statements and Cash Flow Statements for tax matters. Even then, it does not refer to SAK EMKM. During this pandemic, we only focus on how to market our handicrafts because the art market is empty and there are no visitors. If you have to study SAK EMKM, it will only add to the burden on your mind. I'm just a high school graduate so it's a little bit difficult to understand the standard language. Therefore, at this time, I have not thought about making financial reports, other than not, hee hee hee, hee hee" he said with a laugh.

So, almost all MSMEs actors do not have sufficient time and ability to prepare financial reports and study SAK EMKM during the Covid-19 pandemic. At this time they only focus on thinking how their business will not go bankrupt, stay alive to pay employee salaries and family living expenses. The education level of MSME actors greatly influences the level of understanding of SAK EMKM. Wicaksono (2016) reveals that the educational background of business actors affects perception of standardbased financial reports. The higher the education level of MSME actors, the more open the minds of many things related to their business will be. In addition, it also gives an influence on the response to financial accounting standards, especially SAK EMKM for the purpose of preparing financial statements. The education reflects the understanding financial statements presented fit in with SAK EMKM.

The difficulty is, the marketing conditions during the pandemic make a difficult choice for EMKM actors. The exhaustion of resources devoted to focusing on sales often leads to neglect of several other things, one of which is the preparation of reports according to standards. The business language that is expected to be able to bridge the principals (investors) and agents (EMKM) will in fact only be able to happen if the language conveyed is not only up to standard but also generates good profits. Reports that are prepared according to standards, but minimal profits are also only bad news for investors, therefore EMKM is more focused on sales and cutting high costs, one of which is the cost of preparing financial reports.

\section{Conclusion}

\subsection{Conclusion}

This study reveal how the meaning of the existence of SAK EMKM by MSME actors during the Covid19 pandemic in Batu. The findings reveal that MSME actors interpret SAK EMKM as a God of Help, as antiques and increase the workload. One of the MSME actors considers SAK MSMEs to be a God of Help during the economic crisis due to the Covid-19 pandemic. The demand for its products is increasing so it requires additional capital from the bank meskipun hanya berupa laporan sederhana yang mampu mereka susun. One of the requirements for applying for credit is a financial report prepare accoding to SAK EMKM. This opinion also supports opinion of previous research on MSME actors in North Sumatra (Ardila, 2019). 
The MSMEs actors other, give a point of view that SAK EMKM as Antiques in huge loss business condition. SAK EMKM is an Items that should not be held and only for display because the important thing to think about is a business strategy so that the business can survive at the Covid-19 pandemic. This opinion also supports the findings of several MSMEs in the Banjar village (Rizky, 2019). The last, SAK EMKM is considered to increase the workload. MSME actors only think about producing and marketing their products, so they don't think about compiling financial reports, especially according to the SAK EMKM. The informant's education is only high school, makes the less understanding, difficult and adds to the workload.

\subsection{Limitations}

This research has been carried out in accordance with scientific procedures, however, it still has the following limitations:

1. Researchers found that MSMEs actors as Informant could not give intense opinions because health protocol.

2. Researchers have limited time for interviews because the informant tired after work or was serving consumers that make them not focused.

\subsection{Suggestions}

Based on the research limitations, Researchers provide suggestions for further research as follows:

1. For MSMEs (actors) be more active in learning about SAK EMKM in order to be able to create financial reports using SAK EMKM to improve the quality of financial reports even during the Covid-19 pandemic. In addition, to make it easier to prepare financial reports, you can use accounting software, for example: Accurate Accounting, MYOB Accounting, and others.

2. For the Government or related agencies. The development, training, and mentoring programs for MSMEs should be improved in relation to the preparation of financial reports based on SAK EMKM.

3. For Further Researchers. The MSMEs sector being researched can be expanded to other sectors and add informants from official service or heads of public department related

\section{References}

1. Alfitri, A., Ngadiman, \& Sohidin. (2014). Application of Financial Accounting Standards for Entities Without Public Accountability (SAK-ETAP) in Micro, Small and Medium Enterprises (MSMEs) Furniture Craftsmen, Gondangsari Village, Juwiring District, Klaten Regency. Jupe UNS, 2(2), 135147

2. Althafairi, B., Alhoumaida, N., Saxena, M., \& Almsri, Z. (2019). Case study-AMAZON. Journal of The Community Development in Asia, 2(2), 1-8.

3. Ardila, I., Zurriah, R., \& Suryani, Y. (2019). Preparation of financial statements based on financial accounting standards for micro, small and medium entities. International Journal of Accounting \& Finance in Asia Pasific (IJAFAP), 2(3), 1-6. DOI: https://doi.org/10.32535/ijafap.v2i3.584.

4. Atkinson, R.L., Atkinson, R.C., Hilgard, E.R. (1991). Introduction to Psychology. Edisi Delapan. Jakarta: Erlangga.

5. Haryanti, M.D \& Hidayah, I. (2018, July 24). Portrait of Indonesian MSMEs: The Little One Who Plays a Big Role. Retrieved from https://www.ukmindonesia.id/baca-artikel/62.

6. Ikatan Akuntan Indonesia (IAI). (2016a). Helping SMEs to Achieve Bankable Status, IAI Validates SAK EMKM. Retrieved from http://iaiglobal.or.id/v03/berita-kegiatan/detailberita-960=bantu-umkmraih-status-\%3Ci\%3Ebankable\%3Ci\%3E-iai-sahkan-sak-emkm.

7. Ikatan Akuntan Indonesia (IAI). (2016b). IAI Prepares New SAK Pillar for MSMEs. Retrieved from http://iaiglobal.or.id/v03/public_hearing/detail_ph-1.html.

8. Ikatan Akuntan Indonesia (IAI). (2016c). Financial Accounting Standards for Micro, Small, and Medium Entities. Jakarta: Graha Akuntan. 
9. Kee, D. M. H., Toh, A. L., Chong, J. H., Teng, Y. M., Ooi, S. J. C., \& Chong, R. X. J. (2021). The Impact of Covid-19 on McDonald's Business: A Case Study of Malaysia. International Journal of Accounting \& Finance in Asia Pasific (IJAFAP), 4(2), 46-57. DOI: https://doi.org/10.32535/ijafap.v4i2.1116.

10.Lestari, W. S., \& Priyadi, M. P. (2017). Factors Affecting the Quality of SAK-ETAP-Based Financial Reports on MSMEs. Jurnal IImu dan Riset Akuntansi, 6(10), 1-20.

11.Miles, Matthew B., Huberman, A.M \& Saldana, J. (2014). Qualitative Data Analysis, A Methods Sourcebook (Edisi 3). SAGE Publications.

12.Moleong, L. J. (2016). Qualitative Research Methodology. Bandung: PT. Remaja Rosdakarya.

13.Nair, R. K., Reddy, L. S., Verma, P., Pandey, R., Yuwono, S., Sin, L. G., ... \& Yu, T. P. (2021). The Impact of COVID 19 Towards International Business Strategy: A study of Coca-Cola Company. International Journal of Accounting \& Finance in Asia Pasific (IJAFAP), 4(2), 73-92.

14.DOI: https://doi.org/10.32535/ijafap.v4i2.1116.

15.Prayitno, E., Mauidzoh, U., Sukmawaty, W. E. P., \& Tarigan, N. L. L. (2020, October). Empowerment of Lurik Woven Small and Medium Enterprises to Face the Global Market with Multi Disciplines. In Journal of International Conference Proceedings (JICP), 3(2), 223-227).

DOI: https://doi.org/10.32535/jicp.v0i0.898.

16.Presiden Republik Indonesia. (2021). Government Regulation of the Republic of Indonesia Number 7 of 2021 concerning Ease, Protection, and Empowerment of Cooperatives and Micro, Small and Medium Enterprises.

17.Prihandoko, P., Setyawati, D. M., \& Widiyanto, S. (2020, October). Development of Business Management and Marketing of Handy Crafts Products Based on Online Marketing Partnership Strategy. In Journal of International Conference Proceedings (JICP), 3(2), 1-7.

DOI: https://doi.org/10.32535/jicp.v0i0.898.

18. Rakhmat, J. (2005). Communication Psychology. Bandung: PT Remaja Rosdakarya.

19. Rizky, M. (2019). The Identification of Financial Literacy Level (Accounting) of MSMEs Actors in the Wetlands Area (Study of MSMEs Actors in Pemakuan Village, Banjar Regency). International Journal of Accounting \& Finance in Asia Pasific (IJAFAP), 2(2), 1-6.

DOI: https://doi.org/10.32535/ijafap.v2i2.535.

20.Saputra, D. (2021). BI Survey: 87.5 Percent of Indonesian MSMEs Affected by the Covid-19 Pandemic). Retrieved from https://ekonomi.bisnis.com/read/20210319/9/1370022/survei-bi-875persen-umkm-indonesia-terdampak-pandemi-covid-19.

21.Santia, T. (2020, September 4). How many MSMEs are there in Indonesia? This is the Count. Liputan6.com. Retrieved from https://www.liputan6.com/bisnis/read/4346352/berapa-jumlahumkm-di-indonesia-ini-hitungannya.

22.Sarwono, W, Sarlito dan Meinarno, A.E. (2010). Social Psychology. Jakarta: Salemba Humanika

23.Sekaran, U., \& Bougie, R. (2013). Research Methods for Business: A skill-Building Approach. United Kingdom: John Wiley \& Sons Ltd

24.Sinha, R., Nair, R. K., Naik, V., Ganatra, V., Singri, P., Singh, P., ... \& Modawal, I. (2021). New Norm in Consumer Buying Pattern: Online Shopping Swing amid the Coronavirus Pandemic. International Journal of Accounting \& Finance in Asia Pasific (IJAFAP), 4(2), 118-128.

DOI: https://doi.org/10.32535/ijafap.v4i2.1119

25.Sugiyono. (2012). Quantitative, Qualitative, and R\&D Research Methods. Bandung: Alfabeta.

26.Wicaksono, A. L. (2016). Analysis of Factors Affecting Perceptions of Micro, Small and Medium Enterprises About the Importance of Financial Reporting Based on SAK ETAP (Empirical Study on MSMEs in Jember Regency). Artikel IImiah Mahasiswa. Retrieved from http://repository.unej.ac.id/handle/123456789/73728 